AperTO - Archivio Istituzionale Open Access dell'Università di Torino

\title{
Compost-sourced substances (SBO) as feedstuff additives in rabbit production
}

\section{This is the author's manuscript}

Original Citation:

Availability:

This version is available http://hdl.handle.net/2318/1558330

since 2020-07-08T11:47:30Z

Published version:

DOI:10.1016/j.anifeedsci.2016.02.005

Terms of use:

Open Access

Anyone can freely access the full text of works made available as "Open Access". Works made available under a Creative Commons license can be used according to the terms and conditions of said license. Use of all other works requires consent of the right holder (author or publisher) if not exempted from copyright protection by the applicable law. 


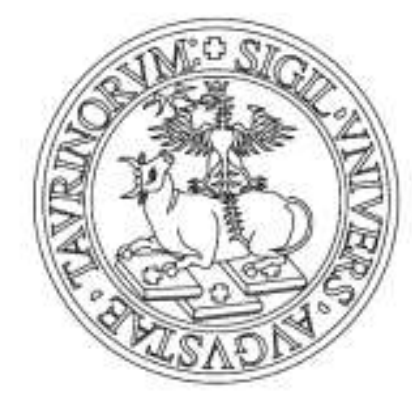

\section{UNIVERSITÀ DEGLI STUDI DI TORINO}

The Accepted Author Manuscript (AAM):

is copyrighted and published by Elsevier. It is posted here by agreement between Elsevier and the University of Turin. Changes resulting from the publishing process - such as editing, corrections, structural formatting, and other quality control mechanisms - may not be reflected in this version of the text. The definitive version of the text was subsequently published in:

Animal Feed Science and Technology

Volume 214, Pages 66-76

\section{Compost-sourced substances (SBO) as feedstuff additives in rabbit production}

Authors: D. Biagini, L. Gasco, R. Rosato, P.G. Peiretti, F. Gai, C. Lazzaroni, C. Montoneri, M. Ginepro.

doi: 10.1016/j.anifeedsci.2016.02.005

The definitive version is available at: La versione definitiva è disponibile alla URL:

http://www.sciencedirect.com/science/article/pii/S0377840116300554 
Compost-sourced substances (SBO) as feedstuff additives in rabbit production

D. Biagini ${ }^{a},{ }^{*}$, L. Gasco ${ }^{b}$, R. Rosato ${ }^{\text {c }}$, P.G. Peiretti ${ }^{d}$, F. Gai e, C. Lazzaroni ${ }^{\dagger}$, C. Montoneri g, M. Ginepro ${ }^{\text {h }}$

a Dipartimento di Scienze Agrarie, Forestali e Alimentari, Università di Torino. Largo Paolo Braccini 2, 10095 Grugliasco, Italy; e-mail: davide.biagini@unito.it.

b Dipartimento di Scienze Agrarie, Forestali e Alimentari, Università di Torino; Istituto di Scienze delle Produzioni Alimentari, Consiglio Nazionale delle Ricerche. Largo Paolo Braccini 2, 10095 Grugliasco, Italy; e-mail: laura.gasco@unito.it.

c Dipartimento di Chimica, Università di Torino. Via Pietro Giuria 7, 10125 Torino, Italy; email: roberta.rosato@unito.it.

${ }^{d}$ Istituto di Scienze delle Produzioni Alimentari, Consiglio Nazionale delle Ricerche. Largo Paolo Braccini 2, 10095 Grugliasco, Italy; piergiorgio.peiretti@ispa.cnr.it.

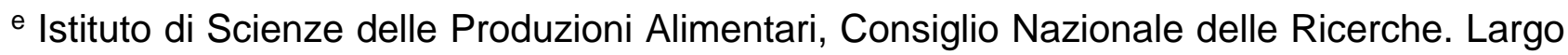
Paolo Braccini 2, 10095 Grugliasco, Italy; francesco.gai@ispa.cnr.it.

f Dipartimento di Scienze Agrarie, Forestali e Alimentari, Università di Torino. Largo Paolo Braccini 2, 10095 Grugliasco, Italy; e-mail: carla.lazzaroni@unito.it.

g 7 Manor View, 158 Crowley Road, Horsham, West Sussex, RH12 4EU, UK.

h Dipartimento di Chimica, Università di Torino. Via Pietro Giuria 7, 10125 Torino, Italy; email: marco.ginepro@unito.it.

" Correspondence to: Dipartimento di Scienze Agrarie, Forestali e Alimentari, Università di Torino. Largo Paolo Braccini 2, 10095 Grugliasco, Italy.

Tel.: +390116708711

E-mail address: davide.biagini@unito.it (D. Biagini) 


\begin{abstract}
Acid soluble bio-organic (SBO) substances have been extracted from plant bio-waste. The SBOs have been tested as feed additives for reared animals. Two trials (T1 and T2, lasting 63 and $56 \mathrm{~d}$, respectively) were carried out to evaluate the effect of different doses of SBOs as feed additives in diets for fattening rabbits (131 and 120 animals from $35 \mathrm{~d}$ of age, respectively) and as binders for the manufacturing of diet pellets to improve their physical properties. The effect of different SBO doses $(0,0.5,2.5 \mathrm{~g} / \mathrm{kg}$ for $\mathrm{T} 1$ and $0,5,10$ $\mathrm{g} / \mathrm{kg}$ for T2) on the growth performance, health status, diet digestibility, carcass and meat traits of rabbits was studied. The aggregating effect of SBOs on feed particles during pelleting was studied by adding 50 and $100 \mathrm{~g} / \mathrm{kg}$ of SBOs to a feed, and then measuring the shear and compression force on the pellets. The results have shown that SBO supplementation of rabbit diets at a concentration of $0.5-10 \mathrm{~g} / \mathrm{kg}$ does not affect the live and slaughtering performances, except for the intestinal tract absorption area (higher in the intestines of rabbits fed with a high supplementation of $\mathrm{SBO} ; \mathrm{P}<0.05$ ) or the dry matter, organic matter, ether extract, fibre and gross energy apparent digestibility of the feed (lower in diets with low or no supplementation of SBO; $\mathrm{P}<0.05$ ). The rabbits fed with the lower SBO dose showed higher values of total anaerobic bacteria and Bacteroides $(P<0.05)$ and a higher cadmium meat content $(P<0.05)$ in $T 1$ and T2 than all others groups. SBOs included at concentrations of 10 and $20 \%$ were also found to affect the physical properties of the pelleted feed. These pellets are more resistant to shear $(\mathrm{P}<0.05)$ and compression force $(\mathrm{P}<0.01)$ in the presence of added SBO. It can be concluded that SBO may be used as a feed additive for rabbits, without any adverse effects on animal productivity and health, as well as to improve the physical properties of pelleted feeds.
\end{abstract}


ADF, acid detergent fibre; ADFI, average daily feed intake; ADL, acid detergent lignin; AIA, acid-insoluble ash; aNDF, neutral detergent fibre; BW, body weight; $\mathrm{C} 1$, control group in trial 1; C2, control group in trial 2; DM, dry matter; DWG, daily weight gain; EE, ether extract; FCR, feed conversion rate; GE, gross energy; HS1 high SBO group in trial 1; HS2, high SBO group in trial 2; HUSs, humic substances; LS1, low SBO group in trial 1; LS2, low SBO group in trial 2; OM, organic matter; PBW, plant bio waste; SBOs, soluble bioorganic compounds; T1, trial 1; T2, trial 2; VFA, volatile fatty acids

Key words: Rabbits; Soluble bio-organic compounds; Live performance; Meat quality; Pelleting.

\section{INTRODUCTION}

The recycling of renewable sources and enhancing natural biological cycles make it possible to develop an integrated production system which offers economic and environmental advantages. Because of increasing urbanization and consumption habits, plant bio-waste (PBW) has become a significant and cost-effective renewable resource (Montoneri et al., 2011). Recent studies have reported that an appropriate processing of these materials can yield soluble substances (SBOs), which are quite effective for both horticulture growth (Sortino et al., 2013) and animal husbandry (Montoneri et al., 2013), with considerable economic and environmental benefits. These substances show structural similarities to humic substances (HUSs) isolated from soil or fossils, which have also proved efficient for the above uses (Honag and Böhme, 2001; Islam et al., 2005; Miśta, 2007). The use of SBOs, in place of HUSs, appears highly desirable for reasons that are linked to the greater availability of PBW and to the need to reduce landfill areas for PBW disposal. The tested SBO levels cover the range of humic substances used to feed swine, broilers and laying hens (De Mercado et al., 2011; Goihl, 2006; Kocabağli at al.; 
2002; Ozturk et al., 2009). Moreover, agriculture and animal husbandry constitute important markets for the potential allocation of large amounts of SBO.

Rabbits are small animals, which are very economic to buy and rear, compared to larger animals, homogenous from a genetic perspective (being mainly derived from crossbreading) and show low inter-individual variability. Moreover, they are characterized by a very short productive cycle (around 90 days), as well as an ease of handling and observation. They require limited space and are taking on an increasingly important role in meat production throughout the world.

Furthermore, rabbits are herbivorous non-ruminants that are able to utilize a wide range of feed resources, and the post-gastric digestion of such animals is influenced by their rich microbial intestinal population (particularly at the caecum level). One of the leading causes of mortality is disease of the digestive apparatus, involving the microbiota. This feature makes the use of rabbits interesting to assess the influence of SBO on animal welfare and intestinal microflora. Moreover, rabbits serve to bridge the gap between the small animal models, which are perhaps more suitable for biomedical research, and larger animals used for animal production. The results of researches on feed additives, growth performance, feed nutrient digestibility and the meat quality of rabbits have recently been published (Trocino et al., 2013; Villamide et al., 2013; Tres et al., 2014; Zhu et al., 2014). The results of the present research, which was conducted on rabbits for the above mentioned reasons, are presented hereafter. The research was conducted with the following two main objectives: to evaluate whether SBOs, as a feed additive, have similar effects to HUSs, particularly on the live and slaughtering performances and meat quality of fattening rabbits, as well as on the digestibility, and on the anatomical (intestinal mucosa) and microbiological modification of the digestive tract, while testing for toxicity considering different doses; the second objective was to investigate the performance of SBOs as binders for the manufacturing of feed pellets and to improve their physical properties. 
Modifying pellet properties is also important for nutritional purposes, since it may improve feed desirability for the animal (Skoch et al., 1983).

\section{MATERIALS AND METHODS}

All the procedures involving animals were conducted according to the Italian laws on animal welfare in scientific experiments (D.Igs 146/01) and were approved by the Welfare Committee of the Dipartimento di Scienze Agrarie, Forestali e Alimentari of the University of Torino (Italy).

\section{Animals, Diets and Live Performance}

The experiment was conducted at a rabbit farm (Carmagnola, Torino, Italy; $44^{\circ} 511000^{2} \mathrm{~N}$, $7^{\circ} 43 \$ 00^{2} \mathrm{E}$, at an altitude of $240 \mathrm{~m}$ above sea level). The SBOs, isolated from composted urban gardening and park trimming residues, and characterized as reported in Table 1, were added as powder to the rabbit feed mixture before pelleting at four levels over two fattening periods (trial 1, T1; trial 2, T2). The rearing cycles were run under semi-controlled environmental conditions (temperature $23 \pm 5^{\circ} \mathrm{C}$, light length $>8$ hours) in a commercial rabbitry, in which 252 weaned crossbred rabbits (132 and 120 Grimaud x Hycole in T1 and T2, respectively) were reared individually in California type cages $(30 \times 30 \times 40 \mathrm{~cm} ; 0.12$ $\mathrm{m}^{2} /$ head) according to standard procedures.

When the rabbits were 35 days old and had an average body weight (BW) of $984 \mathrm{~g}$ (SD $139 \mathrm{~g}$ ), they were randomly assigned to three groups (44 and 40 heads each/per group, in $\mathrm{T} 1$ and $\mathrm{T} 2$ respectively), with the same initial weight and sex proportion (50\% male and $50 \%$ female). Each rabbit reared individually in each cage represents one replication (44 and 40 replications in $\mathrm{T} 1$ and $\mathrm{T} 2$, respectively) and the trials were conducted according to the recommendations and guidelines for nutrition experiments in rabbits (FernándezCarmona et al., 2005). The animals were fed ad libitum for 63 and 56 days in T1 and T2, 
respectively, with an isocaloric (18.8 MJ/kg of dry matter) and isoproteic (179 $\mathrm{g} / \mathrm{kg}$ crude protein on dry matter) diet, enriched with different levels of SBO.

The SBO supplementations were: 0 (control group; C1), 0.5 (low SBO; LS1), $2.5 \mathrm{~g} / \mathrm{kg}$ (high SBO; HS1) and 0 (control group; C2), 5 (low SBO; LS2), $10 \mathrm{~g} / \mathrm{kg}$ (high SBO; HS2), in T1 and T2, respectively. All the diets were pelleted and the animals had free access to clean drinking water. During the trials, the rabbits' feed intake, as well as their initial, intermediate (every 2 weeks) and final live weight, mortality and any diseases present were recorded individually by trained operators after direct observation of the animals twice a day. The daily weight gain (DWG), average daily feed intake (ADFI) and feed conversion rate $(\mathrm{FCR})$ were calculated on the basis of these data.

\section{Digestibility trial and chemical composition of the diets}

The apparent digestibility of the diets was determined, according to Furuichi and Takahashi (1981), during T1, on faeces collected from 48 rabbits (16 subsamples of manure per group) over a period of four days. The collection was started at an age of 42 days, at approximately $0900 \mathrm{~h}$, before the next daily ration was provided, according to the European reference method (Perez et al., 1995). Each pooled faecal sample was placed in a two-layer plastic bag to prevent loss of moisture, and immediately frozen at $-20^{\circ} \mathrm{C}$. The frozen samples were individually mixed thoroughly, pooled and ground in a homogenizer (Tecator, Herndon, VA). Representative samples were then weighed in an aluminium foil pan, dried in a draft oven at $80^{\circ} \mathrm{C}$ to constant weight and stored for chemical analysis. All the analyses were carried out on duplicate samples. The proximate composition of the diets (Table 2) and faeces was determined according to AOAC (2006): preparation of an analytical sample ( 950.02 method); dry matter (DM) content ( 934.01 method); total ash ( 942.05 method); crude protein (CP) content ( 984.13 method); ether extract (EE) content ( 2003.05 method); neutral detergent fibre (aNDF) content ( 2002.04 method); acid detergent fibre (ADF) and acid detergent lignin (ADL) content ( 973.18 method). Gross 
energy (GE) was determined by means of an adiabatic calorimeter bomb (IKA C7000, Staufen, Germany). The acid-insoluble ash (AIA) content of the diets and faeces was determined according to Van Keulen and Young (1977).

The apparent digestibility of the rations was calculated using the indirect digestibility method (Furuichi and Takahashi, 1981), using AIA as an inert marker. DM digestibility was determined as follows:

DM digestibility $(\%)=(1-\mathrm{A} / \mathrm{B}) \times 100$

in which $A$ and $B$ represent the AIA concentrations in the feed and faeces, respectively. The organic matter (OM), CP, EE, aNDF, and GE digestibility were calculated as follows: $\mathrm{X}$ digestibility $(\%)=[1-(\mathrm{A} / \mathrm{B}) \times(\mathrm{XB} / \mathrm{XA})] \times 100$ in which $\mathrm{XA}$ and $\mathrm{XB}$ represent the $\mathrm{OM}, \mathrm{EE}, \mathrm{CP}$, aNDF, and GE concentrations in the feed and faeces, respectively.

\section{Slaughtering performances}

Thirty rabbits (10 per group) were slaughtered in an authorized slaughterhouse at the end of T1, after 24 hours of fasting, in accordance with standard WRSA methods (Blasco et al., 1993). The weights of the carcass, of the commercial skin, the distal part of the fore and hind legs, pluck (thymus, trachea, oesophagus, lungs and heart), liver, kidneys, full gut, full and empty caecum were recorded at slaughtering and the dressing percentage was calculated.

\section{Meat quality traits}

After $24 \mathrm{~h}$ of chilling at $2 \pm 2^{\circ} \mathrm{C}$, the Longissimus lumborum (LL) muscles were excised from the carcasses to measure $\mathrm{pH}$ (triple measurement at $20^{\circ} \mathrm{C}$ with a Crison MicropH 2001, using a combined $3 \mathrm{~mm}$ penetrating electrode ), the colour in the CIELAB space (Lightness, $L^{*}$; redness, $a^{*}$ and yellowness, $b^{*}$; with a Minolta Chromameter Reflectance II CR200/08; Boccard et al., 1981) and cooking losses (Ramirez et al., 2004). 
Samples of the LL muscle were also collected from 15 rabbits (5 per group) at the end of T2 to measure the concentration of some heavy metals (cadmium, Cd; chromium, $\mathrm{Cr}$; copper, $\mathrm{Cu}$; lead, $\mathrm{Pb}$; manganese, $\mathrm{Mn}$; nickel, $\mathrm{Ni}$; zinc, $\mathrm{Zn}$ ) in the meat and in the diet using ICP-AES techniques, according to Baranowska et al. (2006).

\section{Fermentation pattern of the caecum content}

The $\mathrm{pH}$ of the caecal content was immediately measured with a Crison MicropH 2001 device (Crison Instruments, Barcelona, Spain) after the gastrointestinal tract had been removed from the slaughtered rabbit. The caecal content was then removed, put into plastic bottles and stored at $-20{ }^{\circ} \mathrm{C}$ until chemical analysis. Volatile fatty acid (VFA) concentrations were determined in aqueous extracts, according to the method described by Rotolo et al. (2014). In short, samples of the caecal content were weighed $(1 \mathrm{~g})$ and extracted with $5 \mathrm{~mL}$ of $\mathrm{H}_{2} \mathrm{O}$ dd at $20^{\circ} \mathrm{C}$. The mixture was centrifuged for $15 \mathrm{~min}$ at $3000 \mathrm{xg}$. A $1 \mu \mathrm{L}$ aliquot of the extract was injected, using an on-column technique with an autosampler (Dani Instruments SpA, ALS 1000, Cologno Monzese, Italy), into a wide-bore capillary column (SGE BP21 25m x $0.53 \mathrm{~mm}$ internal diameter and $0.5 \mu \mathrm{m}$ film thickness; P/N 054474, SGE International, Ringwood, Victoria, Australia) installed in a gas chromatograph (Dani GC 1000 DPC), running in temperature-programmed mode and equipped with a flame ionization detector and a PTV injection port, used in split mode, with a split vent flow of $100 \mathrm{~mL} / \mathrm{min}$. The detector port was set at $240{ }^{\circ} \mathrm{C}$; hydrogen was used as the carrier gas and the oven temperature was programmed to heat to $50{ }^{\circ} \mathrm{C}$ for $2 \mathrm{~min}$ and from $50^{\circ} \mathrm{C}$ to $190^{\circ} \mathrm{C}$ at $5^{\circ} \mathrm{C}$ per min, with a run time of $30 \mathrm{~min}$. The peak area was measured using a Dani Data Station DDS 1000 device. Each peak was identified and quantified according to pure standards (Sigma Chemical, St. Louis, MO).

\section{Caecum microbiology}

Six rabbits (2 per group) from T1 were slaughtered at 121 days of age to evaluate the long-term effect of the diets on the caecum microbiology, and in particular on the total 
mesophilic bacteria, Bacteroides and total anaerobic bacteria. The rabbits were weighed at slaughtering, the caecum content was collected under aseptic conditions, and samples were transferred immediately to the laboratory for analysis. An aliquot of $10 \mathrm{~g}$ of caecum content was put into Stomacher bags with $90 \mathrm{~mL}$ of physiological solution $(8.5 \mathrm{~g} / \mathrm{L} \mathrm{NaCl}-$ $1.5 \mathrm{~g} / \mathrm{L}$ peptone), according to the methods proposed by Kovács et al. (2006) and Mourão et al. (2006). The obtained solution was homogenised in a Colworth Stomacher 400 (PBI International, Milano, Italy), diluted and inoculated into a specific culture medium, then incubated at different temperatures and for different times: $31 \pm 1^{\circ} \mathrm{C}$ and $48 \mathrm{~h}$ for Enterococci, total Coliforms and total mesophilic bacteria; $31 \pm 1^{\circ} \mathrm{C}$ and $48-72 \mathrm{~h}$ for Bacteroides; $37 \pm 1^{\circ} \mathrm{C}$ and $48-72 \mathrm{~h}$ for anaerobic bacteria. The number of colonies was expressed as log colony-forming units (cfu) per gram of chymus.

\section{Histological examination of the gut}

Samples of rabbit ileum tissues were prepared according to the procedure described by Mourão et al. (2006). Tissue samples were processed in an automated tissue processor and embedded in paraffin wax. Two micrometer paraffin sections were cut and routinely stained with haematoxylin and eosin. Microphotographs were taken with a Nikon Eclipse 80i (Nikon, Japan) microscope with a QImaging camera. Ten intestines were examined for each dietary treatment, and measurements of the villus height, villus width at the crypt/villus junction and at the tip were performed using the Image-Pro Plus 5.1 software (Media Cybernetics Inc., Bethesda, MD), according to a modified version of the method by lji et al. (2001). The villus absorption area was calculated considering the thus obtained values.

\section{Technological properties of the pelleted feeds}

In order to evaluate the aggregating effect on feed particles during pelleting, three additive concentrations were used: 0 (control), 50 (LS) and 100 (HS) g/kg of SBO. Single $10 \mathrm{~mm}$ long and $3 \mathrm{~mm}$ in diameter cylindrical pellets were tested under shear and compression 
force using an Instron 5543 device (Thomas et al., 1996) with 30 replications per group. The shear force was measured perpendicular to the cylindrical pellet with a WarnerBratzler shear device and the crosshead speed was set to $100 \mathrm{~mm} / \mathrm{min}$. The maximum shear force (kgf), the energy at the maximum shear force (kgf-mm) and maximum stress $\left(\mathrm{kgf} / \mathrm{cm}^{2}\right)$ parameters were recorded. The compression force was measured for two compression cycles set to $50 \%$ of the pellet diameter. The recorded parameters were: the maximum force $(\mathrm{N})$ and energy at maximum load $(\mathrm{J})$ for the first and second compression cycles, and material resilience, expressed as the ratio between the maximum force in the first and second compression cycles.

\section{Statistical analysis}

All the data were assessed, after their normal distribution had been tested (Shapiro-Wilk test), by ANOVA (IBM SPSS Statistics 20.0, SPSS Inc., Chicago, IL), separately for T1 and T2, according to the model $y=\mu+\alpha_{i}+\varepsilon_{i j}$ where: $\mu=$ general mean; $\alpha_{i}=$ SBO integration effect; $\varepsilon_{i j}=$ random error effect. Differences in mean values were tested by means of Duncan's test, using a first class error $\alpha=0.05$ to accept the differences as significant.

The death rate was studied by means of Pearson's chi-square test (IBM SPSS Statistics 20.0, SPSS Inc., Chicago, IL), separately for T1 and T2.

\section{RESULTS}

\section{Live performance}

Table 3 shows the live performances of the rabbits recorded during T1. One rabbit in the C1 group died before T1 started, but the groups maintained weights homogeneity. No statistical differences were found for the collected or calculated parameters, that is, for DWG, ADFI and FCR. The absence of any differences in feed intake implies that the 
assumed energy and protein level was the same. The death rate, even though the same between groups, seemed to rise progressively with the SBO dose. Live performances in T2 did not show any statistical differences either (Table 4), but unlike T1, the death rate did not seem to increase with the SBO dose. No specific diseases were recorded in either T1 or T2.

\section{Digestibility of the diets}

The apparent digestibility of the experimental diets is reported in Table 5. CP digestibility was similar for all the diets, while the rabbits fed a diet with $2.5 \mathrm{~g} / \mathrm{kg}$ of SBO showed lower DM $(P<0.05), O M(P<0.01)$ and $G E(P<0.05)$ apparent digestibility coefficients than those fed diets without SBOs. EE and NDF digestibility was lower in diets with $2.5 \mathrm{~g} / \mathrm{kg}$ of SBO $(P<0.05)$ than the other two diets.

\section{Slaughtering performances and meat quality}

As shown in Table 6, the rabbits slaughtered at the end of $\mathrm{T} 1$ had the same final live weight. No differences were found among the groups in terms of dressing percentage, weight of carcass or of anatomical parts, particularly the gut, caecum, kidneys and liver, which could (potentially) be affected by SBO supplementation.

Again no differences were found between the C1, LS1 and HS1 groups for meat quality (Table 7), in terms of $\mathrm{pH}$ at $24 \mathrm{~h}$, colour or cooking losses.

As far as the heavy metal content in both the feed and meat from T2 is concerned (Table 8), higher Cd levels were only found in the meat in the LS2 groups $(P<0.05)$.

\section{Caecum traits and microbiology}

The effects of diets on the caecal characteristics are shown in Table 9. No differences were found in caecum functionality, as can be deduced considering its weight content, $\mathrm{pH}$ and VFA production. Microbial counting showed significant differences $(P<0.05)$ between treatments, in terms of the total anaerobic bacteria and Bacteroides, while the total 
mesophilic bacteria population was unaffected. Rabbits fed the LS1 diet showed higher values of total anaerobic bacteria and of Bacteroides than the other 2 groups (Table 10).

\section{Gut histology}

A histological examination of the ileum sections showed no differences in villus height for the dietary treatments, while a significantly higher villus absorption area $(P<0.05)$ was recorded in the intestine of the rabbits fed HS1 than in the other groups (Table 11).

\section{Technological properties of the pelleted feeds}

The supplementation of SBO in the feeds (Table 12) showed effects on pellet hardness, but not on their cohesion. In fact, the measurements in the Instron device showed a higher maximum shear force and maximum shear stress for the SBO groups (LS and HS) than for group $C(P<0.05)$. In addition, the $1^{\text {st }}$ cycle maximum compression force was higher in LS than in HS and $\mathrm{C}$, and higher in HS than in $\mathrm{C}(\mathrm{P}<0.01)$. No differences were recorded for the other parameters, including the cohesion force.

\section{DISCUSSION}

In the present study, SBO added at a concentration of $0.5-10 \mathrm{~g} / \mathrm{kg}$ to rabbit diets has not appeared to cause any effect on any of the indicators, except for a small $2-9 \%$ decrease in feed digestibility and a more noteworthy $13 \%$ increase in the villus absorption area. The SBO supplementation doses were chosen according to the available literature on soilsourced HUSs. The latter substances, which are chemically similar to SBOs, have been applied as feed supplements to swine and poultry diets at concentrations of $0.2-15 \mathrm{~g} / \mathrm{kg}$ (De Mercado et al., 2011; Goihl, 2006; Kocabağli at al., 2002; Ozturk et al., 2009; Ozturk et al., 2012; Wang et al., 2008). The cited papers report that HUSs improve live and slaughtering performances (e.g. growth and carcass weight) and feed efficiency (e.g. feed conversion). Research by Miśta (2007) and Miśta et al. (2012) has shown that, by acting on intestinal mucosa and on microflora stabilization, the HUSs used as feed additives for 
rabbits may improve nutrient utilization. Apart from the dose, it appears difficult to compare the effects of SBOs sourced from residual vegetable matter and HUSs obtained from different soil sites and preparations, and tested on different species and under different experimental conditions. In addition, conflicting results are reported in the literature for HUS feed additives. Rath et al. (2006), for example, found lower final BW but higher feed conversion ratios in broilers fed diets supplemented with HUSs than broilers fed with a noHUS control diet. Karaoğlu et al. (2004) found a lower daily feed consumption, but the same final BW, DWG and FCR, in broilers fed with HUS-supplemented diets compared to a control group fed with a non-HUS diet.

The lack of effects on the live and slaughtering performance indicators in the present work indirectly indicate that, at the tested concentration, SBOs are not toxic. In fact, the animals exhibited no signs of toxicity, and no pathologies related to the SBO-supplemented diets were recorded. Even though the number of dead animals in the groups varied, the differences between groups due to the lack of significance were not directly imputable to experimental variables, even though further studies are needed to clarify this aspect. The high mortality in all the T1 groups is not unusual: other authors have reported animal death rates of between 8 and 21\% (Kamra et al., 1996; Pascual et al., 2008; Trocino et al., 2005) and up to $70-80 \%$ in the presence of rabbit enteropathy (Le Bouquin et al., 2009; Martínez-Vallespín et al., 2011), which was not present in the present trials. The death rate in T1 appeared to rise slightly when the SBO supplementation was increased (1 rabbit from the consecutive groups). However, this apparent increase was absent in T2 for higher SBO concentrations. These death rate differences between $\mathrm{T} 1$ and $\mathrm{T} 2$ are likely imputable to the different rearing seasons and microclimatic conditions. The data are in agreement with the results obtained by several authors (Karaoğlu et al., 2004; Ozturk et al., 2012; Rath et al., 2006), who found no differences in mortality rates and no adverse health effects on broiler chickens fed HUS diets. Cetin et al. (2011) suggest that a HUS- 
supplemented diet may be able to cope with social stress and hence improve the health status of laying hens.

Another important aspect considered to evaluate potential toxicity is the heavy metal accumulation in meat due to a specific diet. . This could arise from the diet ion-exchange power, as reported by Peña-Méndez et al. (2005) for calcium humate, which could affect the retention level of heavy metals in feeds and/or transferred from the feed to the animal meat. The level of heavy metals recorded in the present work, both for the feeds and meat, were not statistically different between I groups, except for the cadmium levels in the LS2 group meat. In all cases, the heavy metals were well below the legal threshold (Reg. EC No 466/2001). Thus, no risk to human health can (reasonably) be expected, even at the highest SBO concentration feed level considered in this rabbit study.

Meat quality is another key indicator that can be used to evaluate the performance of SBO as a dietary supplement. Several authors have found different responses when feeding animals diets supplemented with HUSs. Ozturk et al. (2012) found that broilers fed these substances show lighter and darker thigh and breast meat, respectively, with a $\mathrm{pH}$ value and a water-holding capacity that varied according to the supplementation level. In the present work, the meat $\mathrm{pH}$ at $24 \mathrm{~h}\left(\mathrm{pH}_{24}\right)$ was found to be between 5.68 and 5.71 , which is slightly higher than that observed by Miśta et al. (2012) in New Zealand White rabbits fed diets containing 5-10 \% humic-fatty acid preparations. These authors reported a greater effect on $\mathrm{pH}_{24}$ of the $10 \%$ humic-fatty acid preparation. Other studies performed on broilers have reported that HUS-supplemented diets actually lower meat pH (Aksu et al., 2005; Esenbuğa et al., 2008).

Dietary supplements may affect caecal fermentation, with significant consequences on the growth and excretion. Diet composition usually affects caecal fermentation in growing and adult rabbits (Carabaño et al., 1988; Gidenne et al., 1998; Gidenne and Bellier, 2000; Xiccato et al., 2003), in particular as the caecum of rabbits is characterised by the 
presence of a rich microbial community. The presence of this microbial community is essential to maintain their intestinal health, which is achieved through the prevention of colonization by pathogenic bacteria strains, and it plays an important role in feed digestion through the fermentation of non-absorbed nutrients (Carabaño et al., 2006). The data in Table 10 show the absence of significant effects of SBOs on the caecal fermentation pattern, thus suggesting it has no effect on the digestive ecosystem. The effect of diet on digestibility evidenced by the data in Table 5 could be due to the presence of antinutritional substances in the SBOs, which could have caused a reduction in the digestibility of DM, OM, EE and NDF in the HS group but without significant differences in the digestibility of $\mathrm{CP}$ and digestible energy between groups. However, the digestion coefficients are, similar to those found for other rabbit diets (Peiretti et al., 2010; Peiretti et al., 2012). On the other hand, El-Husseiny et al. (2008) found that feeds containing 1.25-2.50 g/kg HUS enhanced the digestibility coefficients of most nutrients in broiler chicks compared to a control diet. In addition, with reference to fermentation efficiency, no differences in $\mathrm{pH}$ or VFA caecum content have been found between treatments in the present study. Miśta (2007) instead reported a higher propionic acid content in the total VFA volume and a lower $\mathrm{pH}$ of the rabbit caecal content in treated groups compared to the control group for a diet containing 100 and $150 \mathrm{~g} / \mathrm{kg}$ of an in vitro tested humic-mineral-fatty acid preparation .

Taken together, the results of this work point out possible avenues for further (worthwhile) research with a view to confirming the reduction in gas production from slurry generated by animals fed with SBO-supplemented diets. Confirmation of this result can in fact be expected, based on the results of recent work with the SBOs used in this study. In fact, Montoneri et al. (2013), who have reported the in vitro fermentation of protein feeds in the caecal content collected from slaughtered pigs, have shown that a supplementation of 1 $\mathrm{g} / \mathrm{kg} \mathrm{SBO}$ to the fermentation liquor reduces gas production and digestate ammonia. A reduction in gas emissions has also been reported for stored manure collected from 
rabbits fed diets supplemented with SBOs (Biagini et al., 2012; Dinuccio et al., 2012; Dinuccio et al., 2013).

Taken together, all these results suggest that it is feasible to feed rabbits diets enriched with SBOs, as they do not modify the live performance or product quality, but do reduce the release of greenhouse gases from stored manure with consequent environmental benefits. Further work is needed to evaluate whether feeding animals with SBO diets to produce fewer greenhouse gases and digestate ammonia could be a more interesting strategy than supplementing SBO in manure to control its biodegradation after spreading it over soil.

The final significant issue regarding the animal diets investigated in this work concerns the effect of SBOs on the physical properties of the pelleted feeds. The amount of energy required to break or shear the pellet depends to a great extent on the physical-chemical properties of the diet ingredients and additives, as the crystallisation processes that take place in the pellet during cooling/drying and capillary forces account for most of the binding particles (Thomas et al., 1996, 1998). SBO feed supplementation might affect the properties of pellets, as SBOs could interact with the feed particles during pelleting, particularly in the warming phase. Two significant properties of the pellet are hardness and shear force. The former refers to the resistance that the cylinder provides to breakage when subjected to pressure. The latter is related to the fact that rabbits have highlydeveloped continuously-growing incisors. During feeding, their teeth exert a shear force on the cylinder that consumes the teeth, indispensable thing for rabbits. The data in Table 12 show that 50 and $100 \mathrm{~g} / \mathrm{kg} \mathrm{SBO}$ feed supplementations significantly increased both the shear and compression forces of the pellet. However, the effects on the physical properties of the pellet have only been demonstrated for pellets containing much higher SBO concentrations than those used in the rabbit diet. Therefore, further trials are necessary to investigate the effects on the live and slaughtering performance of rabbits fed 
feeds containing 50 and $100 \mathrm{~g} / \mathrm{kg}$ of SBO in order to assess the commercial viability of the thus reinforced pellets.

\section{CONCLUSIONS}

It has here been shown that plant biowaste-sourced SBOs used as feed additives do not affect the live and slaughtering performances or meat quality of fattening rabbits, or even the microbiological population of the rabbits' digestive tract. Thus, no adverse effect can (reasonably) be expected on the health of rabbits and humans due to the presence of SBOs in the animal diet, up to a concentration of $10 \mathrm{~g} / \mathrm{kg}$. Moreover, the use of SBOs as feed additives has been shown to enhance the physical properties of pelleted feeds. The results of this work, coupled to those of previous works reporting that SBOs lower gas production and digestate ammonia in in vitro pig caecal fermentation and in stored rabbit manure, suggest that the use of SBO supplementation in feeds could be an intriguing and efficient strategy for eco-friendly livestock rearing and/or maintenance. As other studies have also pointed out that these SBOs are efficient soil additives for horticulture, they show great potential for the development of a sustainable agricultural system.

\section{CONFLICT OF INTEREST}

The authors declare that there was no conflict of interest associated to this publication.

\section{ACKNOWLEDGEMENTS}

This work was carried out partly with Ministero delle Politiche Agricole funds within the Agrienergia project. The authors are grateful to the following private and/or public institutions: (i) Acea Pinerolese Spa in Pinerolo (Italy) for supplying the SBO sourcing material; (ii) Studio Chiono ed Associati in Rivarolo Canavese (Italy) for making the pilot equipment and services available for the production of the SBOs. 


\section{REFERENCES}

Aksu, M.I., Karaoğlu, M., Kaya, M., Esenbuğa, N., Macit, M., 2005. Effect of dietary humate on the $\mathrm{pH}$, TBARS and microbiological properties of vacuum and aerobicpacked breast and drumstick meats of broilers. J. Sci. Food Agric. 85, 1485-1491. AOAC, 2006. Official Methods of Analysis of the AOAC. 18 ${ }^{\text {th }}$ ed. Assoc. Off. Anal. Chem., Gaithersburg, MD.

Baranowska, I., Barchanska, H., Pacak, E., 2006. Procedures of trophic chain samples preparation for determination of triazines by HPLC and metals by ICP-AES methods. Environ. Pollut. 143, 206-211.

Biagini, D., Dinuccio, E., Rosato, R., Lazzaroni, C., Balsari, P., Montoneri, E., 2012. Effect of a feed additive from plant residues on gaseous emissions from rabbit stored manure. In: Hassouna, M., Guingand, N. (Eds.), Emissions of gas and dust from livestock, IFIP, Paris, France, pp. 167-170.

Blasco, A., Ouhayoun, J., Masoero, G., 1993. Harmonization of criteria and terminology in rabbit meat research. World Rabbit Sci. 1, 3-10.

Boccard, R., Butcher, L., Casleels, E., Cosentino, E., Dransfield, E., Hood, D.E., Joseph, R.L., MacDougall, D.B., Rhodes, D.N., Schön, I., Tinbergen, B.J., Touraille, C., 1981. Procedures for measuring meat quality characteristics in beef production experiments. Report of a working group in the Commission of the European Communities (CEC), beef production research programme. Livest. Prod. Sci. 8, 385-397.

Carabaño, R., Fraga, M.J., Santomá, G., de Blas, J.C., 1988. Effect of diet on composition of cecal content and on excretion and composition of soft and hard feces of rabbits. J. Anim. Sci. 66 901-910. 
Carabaño, R., Badiola, I., Licois, D., Gidenne, T., 2006. The digestive ecosystem and its control through nutritional or feeding strategies. In: Maertens, L., Coudert, P. (Eds.), Recent advances in rabbit sciences. ILVO, Merelbeke, Belgium, pp. 211-227.

Cetin, E., Guclu, B.K., Cetin, N., 2011. Effect of dietary humate and organic acid supplementation on social stress induced by high stocking density in laying hens. J. Anim. Vet. Adv. 10, 2402-2407.

De Mercado, E., Tomás, C., Gómez-Izquierdo, E., Gómez-Fernández, J., 2011. Respuesta productiva a la adición de distintos aditivos zootécnicos (Prebióticos, ácidos orgánicos y extractos vegetales) en dietas para cerdos grasos. XIV Jornadas sobre Producción Animal, Zaragoza, Spain, pp. 282-284.

Dinuccio, E., Biagini, D., Rosato, R., Balsari, P., Lazzaroni, C., Montoneri, E., 2012. Effect of a green compost extract added to rabbit feed on nitrogen balance and ammonia and nitrous oxide emissions from stored slurry. In: Proc. $17^{\text {th }} \mathrm{N}$ Workshop, Wexford, Ireland, pp. $456-457$.

Dinuccio, E., Biagini, D., Rosato, R., Balsari, P., Lazzaroni, C., Montoneri, E., 2013. Use of acid soluble bio-organic substances extract as rabbits feed additive to reduce manure gases emission during storage. Advances in Animal Biosciences 4 (Special Issue 2), 515.

El-Husseiny, O.M., Abdallah, A.G., Abdel-Latif, K.O., 2008. The influence of biological feed additives on broiler performance. Int. J. Poult. Sci. 7, 862-871.

Esenbuğa, N., Macit, M., Karaoğlu, M., Aksu, M.I., Bilgin, O.C., 2008. Effects of dietary humate supplementation to broilers on performance, slaughter, carcass and meat colour. J. Sci. Food Agric. 88, 1201-1207.

Fernández-Carmona, J., Blas, E., Pascual, J.J., Maertens, L., Gidenne, T., Xiccato, G., Garcia, J., 2005. Recommendations and guidelines for applied nutrition experiments in rabbits. World Rabbit Sci., 13, 209-228. 
Furuichi, Y., Takahashi, T., 1981. Evaluation of acid insoluble ash as a marker in digestion studies. Agr. Biol. Chem. Tokyo 45, 2219-2224.

Gidenne, T., Bellier, R., van Eys, J., 1998. Effect of the dietary fibre origin on the digestion and on the cecal fermentation pattern of the growing rabbit. Anim. Sci. 66, 509-517.

Gidenne, T., Bellier, R., 2000. Use of digestible fibre in replacement to available carbohydrates. Effect on digestion, rate of passage and cecal fermentation pattern during the growth of the rabbit. Livest. Prod. Sci. 63, 141-152.

Goihl, J., 2006. Humic substances may improve pig growth. Feedstuffs, 78, 12-13. Honag, T.L., Böhme, M., 2001. Influence of humic acid on the growth of tomato in hydroponic systems. Acta Hortic. 548, 451-458.

Kamra, D.N., Chaudhary, L.C., Singh, R., Pathak, N.N., 1996. Influence of feeding probiotics on growth performance and nutrient digestibility in rabbits. World Rabbit Sci. 4, 85-88.

Karaoğlu, M., Macit, M., Esenbuğa, N., Durdag, H., Turgut, L., and Cevdet Bilgin, O., 2004. Effect of supplementation humate at different levels on the growth performance, slaughter and carcass traits of broilers. Int. J. Poultry Sci. 3, 406-410.

Kocabağli, N., Alp, M., Acar, N., Kahraman, R., 2002. The effects of dietary humate supplementation on broiler growth and carcass yield. Poultry Sci. 81, 227-230.

Kovács, M., Szendro, Z., Milisits, G., Bóta, B., Bíró-Németh, E., Radnai, I., Pósa, R., Bónai, A., Kovács, F., Horn, P., 2006. Effect of nursing methods and faeces consumption on the development of the bacteroides, lactobacillus and coliform flora in the caecum of the newborn rabbits. Reprod. Nutr. Dev. 46, 205-210.

lji, P., Saki, A.A., Tivey, D.R., 2001. Intestinal structure and function of broiler chickens on diets supplemented with a mannan oligosaccharide. J. Sci. Food Agric. 81, 1186-1192. Islam, K.M.S., Schuhmacher, A., Gropp, J.M., 2005. Humic Acid Substances in Animal Agriculture. Pak. J. Nutr. 4, 126-134. 
Le Bouquin, S., Robert, J.L., Larour, G., Balaine, L., Eono, F., Boucher, S., Huneau, A., Michel, V., 2009. Risk factors for an acute expression of Epizootic Rabbit Enteropathy syndrome in rabbits after weaning in French kindling-to-finishing farms. Livest. Sci. 125, 283-290.

Martínez-Vallespín, B., Martínez-Paredes, E., Ródenas, L., Cervera, C., Pascual, J. J., Blas, E., 2011. Combined feeding of rabbit female and young: Partial replacement of starch with acid detergent fibre or/and neutral detergent soluble fibre at two protein levels. Livest. Sci. 141, 155-165.

Miśta, D., 2007. The effect of dietary supplement - Humobentofen on rabbit cecal parameters of microbial fermentation at in vitro study. Electron. J. Pol. Agric. Univ., 10 (4), \#13. http://www.ejpau.media.pl/volume10/issue4/art-13.html. (Accessed 10 October 2014.)

Miśta, D., Rząsa, A., Szmańko, T., Zawadzki, W., Styczyńska, M., Pintal, A., Króliczewska, B., 2012. The effect of humic-fatty acid preparation on production parameters and meat quality of growing rabbits. Ann. Anim. Sci. 12, 117-126.

Montoneri, C., Montoneri, E., Tomasso, L., Piva, A., 2013. Compost derived substances decrease feed protein $\mathrm{N}$ mineralization in swine cecal fermentation. J. Agric. Sci. 13, 3144.

Montoneri, E., Mainero, D., Boffa, V., Perrone, D.G., Montoneri, C., 2011. Biochemenergy: a project to turn an urban wastes treatment plant into biorefinery for the production of energy, chemicals and consumer's products with friendly environmental impact. Int. J. Global Environmental Issues 11, 170-196.

Mourão, J.L., Pinheiro, V., Alves, A., Guedes, C.M., Pinto, L., Saavedra, M.J., Spring, P., Kocher, A., 2006. Effect of mannan oligosaccharides on the performance, intestinal morphology and cecal fermentation of fattening rabbits. Anim. Feed Sci. Technol. 126, 107-120. 
Ozturk, E., Coskum, I., Ocak, N., Erener, G., 2009. Effect of dietary humic substances on egg production and egg shell quality of hens after peak laying period. Afr. J. Biotechnol. 8, 1155-1159.

Ozturk, E., Ocak, N., Turan, A., Erener, G., Altop, A., 2012. Performance, carcass, gastrointestinal tract and meat quality traits, and selected blood parameters of broilers fed diets supplemented with humic substances. J. Sci. Food Agric. 92, 59-65.

Pascual, M., Pla, M., Blasco, A., 2008. Effect of selection for growth rate on relative growth in rabbits. J. Anim. Sci. 86, 3409-3417.

Peiretti, P.G., Gai, F., Meineri, G., Zoccarato, I., Gasco, L., 2010. Apparent digestibility of compound diets with increasing levels of perilla (Perilla frutescens L.) seeds in rabbits. Ital. J. Anim. Sci. 9, 425-428. doi:10.4081/ijas.2010.e81

Peiretti, P.G., Gai, F., Rotolo, L., Gasco, L., 2012. Effects of diets with increasing levels of dried tomato pomace on the performances and apparent digestibility of growing rabbits. Asian J. Anim. Vet. Adv. 7, 521-527.

Peña-Mendez, E.M., Havel, J., Patočka, J., 2005. Humic substances - compounds of still unknown structure: applications in agriculture, industry, environment, and biomedicine. J. Appl. Biomed. 3, 13-24.

Perez, J.M., Lebas, F., Gidenne, T., Maertens, L., Xiccato, G., Parigi-Bini, R., Dalle Zotte, A., Cossu, M.E., Carazzolo, A., Villamide, M.J., Carabaño, R., Fraga, M.J., Ramos, M.A., Cervera, C., Blas, E., Fernandez, J., Falcao e Cunha, L., Bengala Freire, J., 1995. European reference method for in vivo determination of diet digestibility in rabbits. World Rabbit Sci. 3, 41-43.

Rath, N.C., Huff, W.E., Huff, G.R., 2006. Effects of humic acid on broiler chickens. Poultry Sci. $85,410-414$. 
Ramirez, J.A., Oliver, M.A., Pla, M., Guerrero, L., Ariño, B., Blasco, A., 2004. Effect of selection for growth rate on biochemical, quality and texture characteristics of meat from rabbits. Meat Sci. 67, 617-624.

Reg. EC No 466/2001. Commission Regulation (EC) No 466/2001 of 8 March 2001 setting maximum levels for certain contaminants in foodstuffs. OJEC, L 77, 1-13.

Rotolo, L., Gai, F., Peiretti, P.G., Ortoffi, M., Zoccarato, I., Gasco, L., 2014. Live yeast (Saccharomyces cerevisiae var. boulardii) supplementation in fattening rabbit diet: Effect on productive performance and meat quality. Livest. Sci. 162, 178-184.

Skoch, E.R., Binder, S.F., Deyoe, C.W., Allee, G.L., Behnke, K.C., 1983. Effects of pelleting conditions on performance of pigs fed a corn-soybean meal diet. J. Anim. Sci. $57,922-928$.

Sortino, O., Dipasquale, M., Montoneri, E., Tomasso, L., Avetta, P., Bianco Prevot, A., 2013. $90 \%$ yield increase of red pepper with unexpectedly low doses of compost soluble substances. Agron. Sustain. Dev. 33, 433-441.

Thomas, M., van der Poel A.F.B., 1996. Physical quality of pelleted animal feed 1. Criteria for pellet quality. Anim. Feed Sci. Technol. 61, 89-112.

Thomas, M., van Vliet, T., van der Poel, A.F.B., 1998. Physical quality of pelleted animal feed 3. Contribution of feedstuff components. Anim. Feed Sci. Technol. 70, 59-78.

Tres, A., Mangrinyà, N., Bou, R., Guardiola F., Nuchi, C.D., Codony R., 2014. Impact of the oxidative quality of fish oils in feeds on the composition and oxidative stability of chicken and rabbit meat. Anim. Feed Sci. Technol. 196, 76-87.

Trocino, A., Fragkiadakis, M., Majolini, D., Tazzoli, M., Radaelli, G., Xiccato, G.. 2013. Soluble fibre, starch and protein level in diets for growing rabbits: Effects on digestive efficiency and productive traits. Anim. Feed Sci. Technol. 180, 73-82. 
Trocino, A., Xiccato, G., Carraro, L., Jimenez, G., 2005. Effect of diet supplementation with Toyocerin (Bacillus cereus var. toyoi) on performance and health of growing rabbits. World Rabbit Sci. 13, 17-28.

Van Keulen, J., Young, B.A., 1977. Evaluation of acid-insoluble ash as a natural marker in ruminant digestibility studies. J. Anim. Sci. 44, 282-287.

Van Soest, P.J., Robertson, J.B., Lewis, B.A., 1991. Methods for dietary fiber, neutral detergent fiber, and nonstarch polysaccharides in relation to animal nutrition. J. Dairy Sci. $74,3583-3591$.

Villamide, M.J., García, A.I., Llorente, A., Carabaño, R., 2013. Ileal vs. faecal amino acid digestibility in concentrates and fibrous sources for rabbit feed formulation. Anim. Feed Sci. Technol. 182, 100-110.

Wang, Q., Chen, Y.J., Yoo, J.S., Kim, H.J., Cho, J.H., Kim, I.H., 2008. Effects of supplemental humic substances on growth performance, blood characteristics and meet quality in finishing pigs. Livest. Sci. 117, 270-274.

Xiccato, G., Trocino, A., Sartori, A., Queaque, P.I., 2003. Effect of weaning diet and weaning age on growth, body composition and caecal fermentation of young rabbits. Anim. Sci. 77, 101-111.

Zhu, K.H., Xu, X.R., Sun, D.F., Tang, J.L., Zhang, Y.K., 2014. Effects of drinking water acidification by organic acidifier on growth performance, digestive enzymes activity and caecal bacteria in growing rabbits. Anim. Feed Sci. Technol. 190, 87-94. 
Table 12

Technological characteristics of pelletted feed

\begin{tabular}{|c|c|c|c|c|c|}
\hline & $\begin{array}{c}\text { C } \\
(0 \mathrm{~g} / \mathrm{kg})\end{array}$ & $\begin{array}{c}\text { LS } \\
(50 \mathrm{~g} / \mathrm{kg})\end{array}$ & $\begin{array}{c}\text { HUS } \\
(100 \mathrm{~g} / \mathrm{kg})\end{array}$ & SEM & $P$ \\
\hline Maximum shear force (kgf) & $5.02^{\mathrm{b}}$ & $5.78^{\mathrm{a}}$ & $5.95^{\mathrm{a}}$ & 0.15 & 0.049 \\
\hline Energy at maximum shear force (kgf-mm) & 1.33 & 1.23 & 1.74 & 0.14 & 0.255 \\
\hline Share maximum stress $\left(\mathrm{kgf} / \mathrm{cm}^{2}\right)$ & $70.96^{\mathrm{b}}$ & $81.74^{\mathrm{a}}$ & $84.23^{\mathrm{a}}$ & 2.08 & 0.020 \\
\hline $1^{\text {st }}$ cycle compression maximum force $(\mathrm{N})$ & $442.32^{c}$ & $561.43^{a}$ & $504.90^{\mathrm{b}}$ & 11.79 & $<0.001$ \\
\hline $2^{\text {nd }}$ cycle compression maximum force $(\mathrm{N})$ & 250.38 & 284.97 & 275.94 & 7.30 & 0.134 \\
\hline $1^{\text {st }}$ cycle energy to maximum load $(\mathrm{J})$ & 0.14 & 0.14 & 0.16 & 0.009 & 0.692 \\
\hline $2^{\text {nd }}$ cycle energy to maximum load $(\mathrm{J})$ & 0.03 & 0.03 & 0.03 & 0.001 & 0.701 \\
\hline Cohesion force (Resilience) & 0.57 & 0.51 & 0.56 & 0.014 & 0.190 \\
\hline
\end{tabular}

Values within rows with different superscripts $(a, b$ and $c)$ are significantly different $(P<0.05)$. 
Table 11

Rabbits villi measurements and absorption area.

\begin{tabular}{lccccc}
\hline & C1 & LS1 & HS1 & SEM & P \\
& $(0 \mathrm{~g} / \mathrm{kg})$ & $(0.5 \mathrm{~g} / \mathrm{kg})$ & $(2.5 \mathrm{~g} / \mathrm{kg})$ & & \\
\hline Villi height $(\mu \mathrm{m})$ & 561 & 546 & 548 & 9.0 & 0.758 \\
Villi absorption area $\left(\times 10^{3} \mu \mathrm{m}^{2}\right)$ & $140^{\mathrm{b}}$ & $134^{\mathrm{b}}$ & $158^{\mathrm{a}}$ & 3.7 & 0.023 \\
\hline
\end{tabular}

Values within rows with different superscripts $(a$ and $b)$ are significantly different $(P<0.05)$. 


\section{Table 10}

Caecum microbiology.

\begin{tabular}{lccccc}
\hline & C1 & LS1 & HS1 & SEM & P \\
& $(0 \mathrm{~g} / \mathrm{kg})$ & $(0.5 \mathrm{~g} / \mathrm{kg})$ & $(2.5 \mathrm{~g} / \mathrm{kg})$ & & \\
\hline Total mesophilic bacteria (log cfu/g) & 4.86 & 4.74 & 4.47 & 0.10 & 0.252 \\
Total anaerobic bacteria (log cfu/g) & $4.56^{\mathrm{b}}$ & $5.64^{\mathrm{a}}$ & $4.77^{\mathrm{b}}$ & 0.19 & 0.012 \\
Bacteroides (log cfu/g) & $4.40^{\mathrm{b}}$ & $5.49^{\mathrm{a}}$ & $4.72^{\mathrm{b}}$ & 0.18 & 0.017 \\
\hline
\end{tabular}

Values within rows with different superscripts $(a$ and $b)$ are significantly different $(P<0.05)$. 


\section{Table 9}

Caecum content characteristics.

\begin{tabular}{lccccc}
\hline & C1 & LS1 & HS1 & SEM & P \\
& $(0 \mathrm{~g} / \mathrm{kg})$ & $(0.5 \mathrm{~g} / \mathrm{kg})$ & $(2.5 \mathrm{~g} / \mathrm{kg})$ & & \\
\hline Content weight $(\mathrm{g})$ & 127.9 & 127.7 & 139.4 & 3.64 & 0.353 \\
$\mathrm{pH}$ & 6.20 & 6.36 & 6.17 & 0.048 & 0.208 \\
Acetic acid (mg/kg DM) & 12.91 & 10.92 & 12.63 & 0.690 & 0.452 \\
Propionic acid (mg/kg DM) & 1.13 & 1.07 & 1.15 & 0.056 & 0.850 \\
Butyric acid (mg/kg DM) & 2.23 & 1.76 & 2.37 & 0.213 & 0.485 \\
Valerianic acid (mg/kg DM) & 0.19 & 0.17 & 0.19 & 0.010 & 0.884 \\
\hline
\end{tabular}




\section{Table 8}

Heavy metals residues in feed and meat.

\begin{tabular}{|c|c|c|c|c|c|}
\hline & $\begin{array}{c}\text { C2 } \\
(0 \mathrm{~g} / \mathrm{kg})\end{array}$ & $\begin{array}{c}\text { LS2 } \\
(5 \mathrm{~g} / \mathrm{kg})\end{array}$ & $\begin{array}{c}\text { HS2 } \\
(10 \mathrm{~g} / \mathrm{kg})\end{array}$ & SEM & $P$ \\
\hline \multicolumn{6}{|l|}{ Feed } \\
\hline Cadmium (ppm) & 0.08 & 0.08 & 0.08 & - & - \\
\hline Chromium (ppm) & 0.92 & 1.33 & 1.44 & - & - \\
\hline Copper (ppm) & 17.70 & 15.92 & 22.61 & - & - \\
\hline Lead (ppm) & 0.63 & 0.96 & 0.58 & - & - \\
\hline Manganese (ppm) & 59.48 & 74.30 & 81.12 & - & - \\
\hline Nickel (ppm) & 1.36 & 1.77 & 2.08 & - & - \\
\hline Zinc, ppm & 71.98 & 64.11 & 91.17 & - & - \\
\hline \multicolumn{6}{|l|}{ Meat } \\
\hline Cadmium (ppb) & $8.24^{b}$ & $9.38^{\mathrm{a}}$ & $8.50^{\mathrm{b}}$ & 0.18 & 0.028 \\
\hline Chromium (ppb) & 66.48 & 87.10 & 97.31 & 4.99 & 0.088 \\
\hline Copper (ppb) & 376.05 & 393.32 & 390.01 & 13.74 & 0.895 \\
\hline Lead (ppb) & 2.91 & 12.18 & 16.42 & 3.59 & 0.442 \\
\hline Manganese (ppb) & 57.03 & 64.67 & 48.42 & 2.99 & 0.065 \\
\hline Nickel (ppb) & 16.99 & 14.38 & 26.74 & 2.84 & 0.278 \\
\hline Zinc (ppb) & 6762 & 5258 & 5142 & 454.96 & 0.390 \\
\hline
\end{tabular}

Values within rows with different superscripts $(a$ and $b)$ are significantly different $(P<0.05)$. 


\section{Table 7}

Rabbits meat quality.

\begin{tabular}{cccccc}
\hline & C1 & LS1 & HS1 & SEM & P \\
& $(0 \mathrm{~g} / \mathrm{kg})$ & $(0.5 \mathrm{~g} / \mathrm{kg})$ & $(2.5 \mathrm{~g} / \mathrm{kg})$ & & \\
\hline $\mathrm{pH} 24 \mathrm{~h}$ & 5.68 & 5.70 & 5.71 & 0.01 & 0.537 \\
Colour parameters: & & & & & \\
$\mathrm{L}$ & 55.96 & 55.69 & 55.45 & 0.36 & 0.189 \\
$\mathrm{a}$ & 2.35 & 2.15 & 2.56 & 0.17 & 0.645 \\
$\mathrm{~b}$ & 2.37 & 2.21 & 2.40 & 0.14 & 0.863 \\
chroma & 3.37 & 3.12 & 3.56 & 0.21 & 0.703 \\
hue & 45.45 & 47.11 & 42.79 & 1.68 & 0.589 \\
Uncooked sample weight (g) & 15.95 & 17.46 & 18.93 & 0.51 & 0.054 \\
Cooked sampled weight (g) & 10.67 & 11.76 & 12.55 & 0.35 & 0.086 \\
Cooking losses (\%) & 33.08 & 32.60 & 33.81 & 0.33 & 0.337 \\
\hline
\end{tabular}




\section{Table 6}

Rabbits slaughtering performances.

\begin{tabular}{lccccc}
\hline & $\begin{array}{c}\text { C1 } \\
(0 \mathrm{~g} / \mathrm{kg})\end{array}$ & $\begin{array}{c}\text { LS1 } \\
(0.5 \mathrm{~g} / \mathrm{kg})\end{array}$ & $\begin{array}{c}\text { HS1 } \\
(2.5 \mathrm{~g} / \mathrm{kg})\end{array}$ & & SEM \\
& 3319.0 & 3319.8 & 3389.0 & 29.55 & 0.556 \\
\hline Live weight $(\mathrm{g})$ & 1850.7 & 1849.9 & 1920.9 & 20.84 & 0.289 \\
Carcass weight $(\mathrm{g})$ & 546.3 & 557.6 & 551.6 & 7.60 & 0.841 \\
Skin weight (g) & 76.3 & 76.5 & 77.1 & 0.92 & 0.944 \\
Legs weight (g) & 32.9 & 35.5 & 35.2 & 1.09 & 0.589 \\
Pluck weight (g) & 74.8 & 81.4 & 81.3 & 2.33 & 0.425 \\
Liver weight (g) & 18.1 & 18.1 & 19.4 & 0.37 & 0.269 \\
Kidney weight (g) & 550.6 & 528.7 & 549.0 & 10.61 & 0.657 \\
Gut weight (g) & 183.8 & 182.9 & 194.4 & 3.45 & 0.789 \\
Full caecum weight $(\mathrm{g})$ & 55.9 & 55.2 & 55.1 & 1.12 & 0.645 \\
Empty caecum weight $(\mathrm{g})$ & 58.5 & 58.7 & 59.6 & 0.29 & 0.313 \\
Dressing percentage $(\%)$ & & & & & \\
\hline
\end{tabular}




\section{Table 5}

In vivo apparent digestibility of feed.

\begin{tabular}{lccccc}
\hline & C1 & LS1 & HS1 & SEM & P \\
& $(0 \mathrm{~g} / \mathrm{kg})$ & $(0.5 \mathrm{~g} / \mathrm{kg})$ & $(2.5 \mathrm{~g} / \mathrm{kg})$ & & \\
\hline Dry matter (g/kg DM) & $689^{\mathrm{a}}$ & $682^{\mathrm{ab}}$ & $668^{\mathrm{b}}$ & 3.23 & 0.016 \\
Organic matter (g/kg DM) & $699^{\mathrm{a}}$ & $687^{\mathrm{ab}}$ & $673^{\mathrm{b}}$ & 3.28 & 0.003 \\
Crude protein (g/kg DM) & 796 & 786 & 776 & 3.57 & 0.080 \\
Ether extract (g/kg DM) & $811^{\mathrm{a}}$ & $807^{\mathrm{a}}$ & $788^{\mathrm{b}}$ & 3.61 & 0.018 \\
Neutral detergent fibre (g/kg DM) & $422^{\mathrm{a}}$ & $430^{\mathrm{a}}$ & $384^{\mathrm{b}}$ & 7.26 & 0.021 \\
Energy (MJ/kg DM) & 12.5 & 12.8 & 12.5 & 0.08 & 0.216 \\
\hline
\end{tabular}

Values within rows with different superscripts $(a$ and $b)$ are significantly different $(P<0.05)$. 


\section{Table 4}

T2 rabbits live performances.

\begin{tabular}{lccccc}
\hline & C2 & LS2 & HS2 & SEM & P \\
& $(0 \mathrm{~g} / \mathrm{kg})$ & $(5 \mathrm{~g} / \mathrm{kg})$ & $(10 \mathrm{~g} / \mathrm{kg})$ & & \\
\hline Initial rabbits $(\mathrm{n})$ & 40 & 40 & 40 & - & - \\
Final rabbits (n) & 37 & 34 & 38 & - & - \\
LW at 35 d (g) & 1043 & 1036 & 1065 & 9.50 & 0.426 \\
LW at 91 d (g) & 3003 & 3024 & 3030 & 29.45 & 0.926 \\
Feed intake (g) & 6522 & 6781 & 6857 & 74.49 & 0.158 \\
Average daily feed intake (g) & 85.3 & 93.3 & 92.6 & 1.90 & 0.160 \\
Weight gain (g) & 1962 & 1986 & 1960 & 25.09 & 0.895 \\
Average daily weight gain $(\mathrm{g})$ & 35.0 & 35.5 & 35.0 & 0.45 & 0.895 \\
Feed conversion rate $(\mathrm{g} / \mathrm{g})$ & 3.5 & 3.5 & 3.5 & 0.07 & 0.973 \\
Death rate $(\%)$ & 7.5 & 15.0 & 5.0 & - & 0.272 \\
\hline
\end{tabular}




\section{Table 3}

T1 rabbits live performances.

\begin{tabular}{lccccc}
\hline & C1 & LS1 & HS1 & SEM & P \\
& $(0 \mathrm{~g} / \mathrm{kg})$ & $(0.5 \mathrm{~g} / \mathrm{kg})$ & $(2.5 \mathrm{~g} / \mathrm{kg})$ & & \\
& 43 & 44 & 44 & - & - \\
\hline Initial rabbits $(\mathrm{n})$ & 38 & 37 & 36 & - & 0.993 \\
Final rabbits (n) & 934 & 935 & 932 & 11.10 & 0.247 \\
LW at 35 d (g) & 3274 & 3335 & 3214 & 29.07 & 0.556 \\
LW at 98 d (g) & 7674 & 8114 & 7742 & 76.84 & 0.551 \\
Feed intake (g) & 110.2 & 113.9 & 104.9 & 1.22 & 0.230 \\
Average daily feed intake (g) & 2342 & 2302 & 2285 & 23.93 & 0.811 \\
Weight gain (g) & 37.2 & 36.6 & 36.3 & 0.58 & 0.584 \\
Average daily weight gain $(\mathrm{g})$ & 3.3 & 3.1 & 3.4 & 0.10 & 0.662 \\
Feed conversion rate $(\mathrm{g} / \mathrm{g})$ & 11.6 & 15.9 & 18.2 & - & \\
Death rate $(\%)$ & & & & & \\
\hline
\end{tabular}




\section{Table 2}

Chemical composition of experimental diets.

\begin{tabular}{lccccc}
\hline & C1-C2 & LS1 & HS1 & LS2 & HS2 \\
& $(0 \mathrm{~g} / \mathrm{kg})$ & $(0.5 \mathrm{~g} / \mathrm{kg})$ & $(2.5 \mathrm{~g} / \mathrm{kg})$ & $(5 \mathrm{~g} / \mathrm{kg})$ & $(10 \mathrm{~g} / \mathrm{kg})$ \\
\hline Dry matter (g/100 g) & 90.3 & 90.0 & 89.6 & 90.3 & 90.3 \\
Organic matter (g/100 g DM) & 92.9 & 93.2 & 93.5 & 92.7 & 92.5 \\
Crude protein (g/100 g DM) & 18.0 & 17.6 & 17.7 & 18.0 & 18.1 \\
Ether extract (g/100 g DM) & 3.6 & 3.5 & 4.0 & 3.6 & 3.6 \\
Neutral detergent fibre (g/100 g DM) & 37.5 & 37.7 & 39.2 & 37.3 & 37.1 \\
Acid detergent fibre (g/100 g DM) & 19.3 & 21.2 & 22.2 & 19.5 & 19.6 \\
Acid detergent lignin (g/100 g DM) & 4.3 & 4.5 & 4.8 & 4.5 & 4.6 \\
Acid insoluble ash (g/100 g DM) & 1.2 & 0.5 & 0.5 & 0.5 & 0.5 \\
Gross energy (MJ kg DM ${ }^{-1}$ ) & 18.6 & 18.8 & 19.0 & 18.8 & 18.8 \\
\hline
\end{tabular}


Table 1

SBOs chemical characterization.

\begin{tabular}{llll}
\hline Volatile Solids (\%, w/w) & 72.1 & $\mathrm{pH}$ & 8.2 \\
$\mathrm{C}(\%, \mathrm{w} / \mathrm{w})$ & 38.25 & Aluminium (ppm) & 0.49 \\
$\mathrm{~N}(\%, \mathrm{w} / \mathrm{w})$ & 4.01 & Calcium (ppm) & 6.07 \\
$\mathrm{C} / \mathrm{N}(\%, \mathrm{w} / \mathrm{w})$ & 9.54 & Chromium (ppm) & 190 \\
Alkoxy (as C mmol/g) & 4.40 & Copper (ppm) & 202 \\
Aliphatic (as C mmol/g) & 11.80 & Iron (ppm) & 0.77 \\
Amide (as C mmol/g) & 0.32 & Lead (ppm) & 85 \\
Ammine (as C mmol/g) & 2.20 & Magnesium (ppm) & 1.13 \\
Anomeric (as C mmol/g) & 1.30 & Mercury (ppm) & 0.15 \\
Aromatic (as C mmol/g) & 4.10 & Nickel (ppm) & 92 \\
Carboxylic acid (as C mmol/g) & 3.80 & Potassium (ppm) & 3.59 \\
Ketone (as C mmol/g) & 1.50 & Silicon (ppm) & 2.55 \\
Phenol (as C mmol/g) & 1.60 & Sodium (ppm) & 0.16 \\
Phenoxy (as C mmol/g) & 0.64 & Zinc (ppm) & 256 \\
\hline
\end{tabular}

